\title{
THE OPTIMUM QUANTITY OF MONEY RULE IN THE THEORY OF PUBLIC FINANCE
}

\author{
Kent P. KIMBROUGH* \\ Duke University, Durham, NC 27706, USA
}

\begin{abstract}
This paper examines optimal tax policy in a monetary economy in which money serves as an intermediate good that helps facilitate the conversion of scarce resources into final consumption goods by enabling consumers to economize on the costs of transacting. It is shown that in such an environment, even though distorting taxes must be levied for revenue purposes, the optimal tax structure calls for abstaining from inflationary finance and adopting the optimum quantity of money rule.
\end{abstract}

\section{Introduction}

It has been argued by Phelps (1973) and others [see, e.g., Marty (1978), Siegel (1978), Drazen (1979), and Helpman and Sadka (1979)] that when the government must use distorting taxes to raise revenue, it may be optimal, in terms of private sector welfare, to use inflation to drive a wedge between the social marginal cost of producing money (typically taken to be zero) and the private sector's marginal valuation of real balances. Since the private opportunity cost of holding money is the nominal interest rate, this can be achieved by generating an inflation that is sufficient to yield a positive equilibrium nominal interest rate. This public finance type argument provides the main welfare theoretic foundation for resorting to inflationary finance. That is, it is the main argument against implementing Friedman's (1969) optimum quantity of money rule. The objective of this paper is to provide a general equilibrium example in which welfare maximization calls for following the optimum quantity of money rule even though distorting taxes must be levied for revenue purposes. The paper thus demonstrates that the optimum quantity of money rule can be a part of the optimal tax structure and serves to highlight the need to pay careful attention to the role of money in the economy when attempting to assess the welfare implications of inflationary finance.

\footnotetext{
*I wish to thank Phil Brock, Jeremy Greenwood, Torsten Persson, Lars Svensson, and George Tauchen for helpful comments.
} 


\section{The economy}

The economy is inhabited by a large number of identical individuals who transact in competitive markets for goods, factors, and assets. There are $N$ goods, labor is the only factor of production, and money and bonds are the only assets. The representative consumer is interested in maximizing his lifetime utility, $U$, which is given by

$$
U=\sum_{t=0}^{\infty} \beta^{\prime} U\left(c^{\prime}, x^{\prime}\right)
$$

where $0<\beta<1$ is the consumer's subjective discount factor, $x^{t}$ is his period $t$ leisure, and $c^{t}=\left(c_{1}^{t}, c_{2}^{t}, \ldots, c_{N}^{t}\right)$ is his period $t$ consumption bundle with $c_{i}^{t}$ representing his consumption of good $i$ in period $t$.

In addition to leisure, in each period the representative consumer spends his one unit time endowment on labor and transactions (i.e., shopping). The transactions technology is such that the time the consumer must devote to transacting, $v^{t}$, is given by

$$
v^{t}=v\left(m^{t} / p^{t} \cdot c^{t}\right) p^{t} \cdot c^{t}, \quad t=0,1, \ldots
$$

where $m^{t}$ is the consumer's real balances in terms of the numeraire, labor, $p^{t}=\left(p_{1}^{t}, p_{2}^{t}, \ldots, p_{N}^{t}\right)$ is the consumer price vector with $p_{i}^{t}=$ period $t$ relative price of good $i$, and $p^{t} \cdot c^{t} \equiv \sum_{i=1}^{N} p_{i}^{t} c_{i}^{t}$. The transactions technology satisfies the conditions $v^{\prime}(\cdot) \leq 0, v^{\prime \prime}(\cdot)>0, v^{\prime}\left((m / p \cdot c)^{*}\right)=v\left((m / p \cdot c)^{*}\right)=0$. In contrast to Phelps (1973) who models money by entering it into consumers' utility functions, here by holding money consumers can economize on the resources that are necessary for carrying out transactions. The marginal return to holding money, $-v^{\prime}(\cdot)$, is positive and diminishing. When real balances relative to expenditure reach the level $(m / p \cdot c)^{*}$ the gains from holding money are exhausted and, for simplicity, it is assumed that transactions costs are zero when this 'satiation' level of real balances is attained.

The consumer's labor supply, $1-x^{t}-v^{t}$, is used to produce the $N$ consumption goods subject to the constant returns to scale production technology,

$$
\sum_{i=1}^{N} y_{i}^{t}=1-x^{t}-v^{t}, \quad t=0,1, \ldots
$$

where units are defined so that all goods have a labor input coefficient of unity. This means that all producer prices are unity so that consumer prices are simply $p_{i}^{\prime}=1+\tau_{i}^{\prime}$, where $\tau_{i}^{\prime}$ is the consumption tax levied by the government on good $i$ in period $t$. 
The consumer's lifetime budget constraint is

$$
\sum_{t=0}^{\infty} d^{\prime}\left\{p^{\prime} \cdot c^{t}+v^{t}+\left[R^{\prime} /\left(1+R^{\prime}\right)\right] m^{\prime}\right\}=\sum_{t=0}^{\infty} d^{\prime}\left(1-x^{\prime}\right)
$$

where $d^{t}=\prod_{j-1}^{t}\left(1+r^{j-1}\right)^{-1}$ for $t=1,2, \ldots$ and $d^{0}=1$ are the market discount factors for period $t, r^{t}$ is the real interest rate, and $R^{t}$ is the nominal interest rate. The nominal interest rate satisfies the Fisher equation $\left(1+R^{\prime}\right)=$ $\left(1+\pi^{t}\right)\left(1+r^{t}\right)$, where $\pi^{t}$ is the rate of (wage) inflation between periods $t$ and $t+1$. The consumer's intertemporal budget constraint (4) states that, in present value terms, the consumer's non-leisure resources must be spent on consumption purchases, which include taxes paid to the government, transactions services, $v^{t}$, and holding money, $\left[R^{t} /\left(1+R^{t}\right)\right] m^{t}$. To understand this term, note that by holding real balances of $m^{t}$ in period $t$ the consumer foregoes nominal interest payments of $R^{t} m^{t}$ in period $t+1$. The real value of these foregone interest earnings is $R^{t} m^{t} /\left(1+\pi^{t}\right)$ as of period $t+1$ and $R^{t} m^{t} /\left(1+\pi^{\prime}\right)\left(1+r^{t}\right)=\left[R^{t} /\left(1+R^{t}\right)\right] m^{t}$ as of period $t$.

The problem confronting the consumer is to choose $\left\{c^{t}, x^{\prime}, m^{\prime}\right\}_{t=0}^{\infty}$ so as to maximize (1) subject to (2) and (4). The marginal conditions for the consumer's problem implicitly define equilibrium prices as functions of his time profiles of consumption, leisure, and real balances. For $i=1,2, \ldots, N$ and $t=0,1, \ldots$ these functions are given by

$$
\begin{aligned}
& \begin{aligned}
1+\tau_{i}^{\prime} & =p_{i}\left(c^{\prime}, x^{\prime}, m^{\prime}\right) \\
\equiv & {\left[1+v\left(\frac{m^{\prime}}{p^{\prime}(\cdot) \cdot c^{t}}\right)-v^{\prime}\left(\frac{m^{t}}{p^{t}(\cdot) \cdot c^{\prime}}\right) \frac{m^{t}}{p^{t}(\cdot) \cdot c^{t}}\right]^{-1} \frac{U_{i}\left(c^{\prime}, x^{t}\right)}{U_{x}\left(c^{t}, x^{\prime}\right)} }
\end{aligned} \\
& d^{\prime}=d^{\prime}\left(c^{\prime}, x^{\prime}, c^{0}, x^{0}\right) \equiv \beta^{t} U_{x}\left(c^{t}, x^{\prime}\right) / U_{x}\left(c^{0}, x^{0}\right) \\
& R^{t} /\left(1+R^{t}\right)=\phi\left(c^{\prime}, x^{\prime}, m^{\prime}\right) \equiv-v^{\prime}\left(m^{t} / p^{\prime}(\cdot) \cdot c^{t}\right)
\end{aligned}
$$

where

$$
p^{\prime}(\cdot)=\left[p_{1}\left(c^{t}, x^{t}, m^{t}\right), \ldots, p_{N}\left(c^{t}, x^{t}, m^{t}\right)\right]
$$

Using (5) it can be shown that

$$
\partial p_{i}^{t} / \partial m_{t}=v^{\prime \prime} \cdot\left[p_{i}^{t} m^{t} /\left(p^{t} \cdot c^{t}\right)^{2}\right] / \Delta>0, \quad \begin{aligned}
& i=1,2, \ldots, N \\
& t=0,1, \ldots,
\end{aligned}
$$


where

$$
\Delta=1+v-v^{\prime} \cdot\left(m^{\prime} / p^{t} \cdot c^{\prime}\right)+v^{\prime \prime} \cdot\left(m^{\prime} / p^{\prime} \cdot c^{t}\right)^{2}>0
$$

Combining (6) and (7) it can be shown that

$$
\begin{array}{r}
\partial \phi^{t} / \partial m^{t}=-\left(v^{\prime \prime} / p^{t} \cdot c^{t}\right)\left[1+v-v^{\prime} \cdot\left(m^{t} / p^{t} \cdot c^{t}\right)\right] / \Delta<0, \\
t=0,1, \ldots
\end{array}
$$

Besides the representative consumer the other actor in the economy is the government. The government levies consumption taxes, prints money, and issues public debt so as to finance an exogenously determined stream of government expenditures on the economy's $N$ goods subject to the budget constraint

$$
\sum_{t=0}^{\infty} d^{t} g^{t}=\sum_{i=0}^{\infty} d^{\prime}\left\{\tau^{t} \cdot c^{t}+\left[R^{t} /\left(1+R^{\prime}\right)\right] m^{t}\right\}
$$

where $g^{t} \equiv \sum_{i=1}^{N} g_{i}^{\prime}$ is total government purchases in period $t$. The government's inflation tax revenue in period $t$ is $\left[R^{t} /\left(1+R^{\prime}\right)\right] m^{t}$ which equals the consumer's expenditures on holding money. This expenditure accrues to the government because by printing money to finance its period $t$ spending the government avoids interest costs on the public debt with a period $t$ present value of $\left[R^{\prime} /\left(1+R^{\prime}\right)\right] m^{\prime}$ or, equivalently, it buys bonds that yield a stream of income with this present value as of period $t$.

Finally, the economy's general equilibrium requires that all goods, factor, and assets markets clear. In particular, goods market equilibrium requires that $c_{i}^{t}+g_{i}^{t}=y_{i}^{t}, i=1,2, \ldots, N, t=0,1, \ldots$. It is easy to verify that these conditions are consistent with (3), (4), and (9). Factor and asset market equilibrium has already been implicitly assumed in the preceding discussion.

\section{Optimal taxation}

The problem confronting the government is to maximize private sector utility, (1), subject to the government budget constraint, (9), and the optimizing behavior of consumers. The optimal tax structure for this problem has been widely discussed in the public finance literature [see, e.g., Sandmo (1976)]. However, in order to assess the appropriate role of inflationary finance in the optimal tax structure it is not necessary to formally work through the optimal tax problem (although for completeness this is done below). It is a straightforward task to show that even though the government must impose distorting taxes in order to raise revenue, they should eschew inflationary 
finance and adhere to the optimum quantity of money rule. To see this, note that since money appears only in the consumer's budget constraint, his optimization problem can be treated as a two-stage process where he first chooses $\left\{m^{t}\right\}_{i-0}^{\infty}$ to maximize his wealth and then chooses $\left\{c^{t}, x^{t}\right\}_{t=0}^{\infty}$ to maximize his lifetime utility. The first-stage problem yields the first-order condition (6) which can be inverted to show that money demand is given by $m^{\prime}=k\left(R^{\prime} /\left(1+R^{\prime}\right)\right) p^{t} \cdot c^{t}, k^{\prime}=-1 / v^{\prime \prime}<0$. Using this in the consumer's budget constraint and obtaining the first-order conditions for $\left\{c^{t}, x^{t}\right\}_{t=0}^{\infty}$ from the second-stage problem, it can be shown that the consumer's consumption, leisure, and lifetime utility are independent of the particular combination of consumption taxes and nominal interest rates, $\left\{\tau^{t}, R^{t}\right\}_{1-0}^{\infty}$, associated with any given set of effective prices, $\left\{q^{t}, d^{t}\right\}_{r=0}^{\infty}$, where $q^{t}=\left(q_{1}^{t}, q_{2}^{t}, \ldots, q_{N}^{t}\right)$ and $q_{i}^{t}=$ $\left\{1+v(k(\cdot))+\left(R^{\prime} /\left(1+R^{\prime}\right)\right) k(\cdot)\right\}\left(1+\tau_{i}^{\prime}\right)$. It can be seen immediately that government revenue in period $t$ is given by $\left[\left(q^{t}-1\right)-v(k(\cdot))\left(1+\tau^{t}\right)\right] \cdot c^{t}$. From this it is apparent that resorting to inflationary finance and setting $R^{\prime}>0$ is equivalent to taxing consumption at the rate $\left\{q^{t}-1\right\}_{t-0}^{\infty}$ and throwing away, via excessive transactions costs, potential tax revenue amounting to $v(\cdot)\left(1+\tau^{t}\right) \cdot c^{t}$ in each period. In this sense the inflation tax is an inefficient means of raising revenue. By adopting the optimum quantity of money rule the government can raise the revenue it requires at lower effective $\operatorname{tax}$ rates and a higher level of private sector utility, $U$, than it can with any combination of monetary and fiscal policies satisfying its budget constraint that involves inflationary finance. Hence optimal taxation calls for adopting the optimum quantity of money rule. This requires generating an inflation at the rate $\pi^{t}=-r^{t} /\left(1+r^{t}\right)$ which, from the Fisher equation, yields an equilibrium nominal interest rate of zero.

The feature of money that is crucial for this result is that it is an intermediate good, and it is well known from the public finance literature that, given the model's production technology, optimal taxation does not entail taxes on intermediate goods [see Diamond and Mirrlees (1971)]. Faig (1986) and Kimbrough (1986) contain thorough discussions of how the result that the optimum quantity of money rule is a part of the optimal tax structure carries over to alternative economic environments.

Formally, the optimal tax problem facing the government is to choose $\left\{c^{t}, x^{t}, m^{t}\right\}_{t=0}^{\infty}$ to maximize

$$
\begin{aligned}
L= & \sum_{t=0}^{\infty} \beta^{\prime} U\left(c^{\prime}, x^{t}\right)+\lambda \sum_{t=0}^{\infty} d^{t}\left(c^{t}, x^{\prime}, c^{0}, x^{0}\right) \\
& \times\left\{\left[p^{\prime}(\cdot)-1\right] \cdot c^{t}+\phi\left(c^{\prime}, x^{\prime}, m^{\prime}\right) m^{t}-g^{\prime}\right\} \\
& +\sum_{t=0}^{\infty} \mu^{\prime}\left[1-x^{t}-\sum_{i=1}^{N} c_{i}^{\prime}-g^{t}-v\left(m^{\prime} / p^{\prime}(\cdot) \cdot c^{\prime}\right) p^{\prime}(\cdot) \cdot c^{t}\right]
\end{aligned}
$$


The change in welfare associated with a change in real balances in any period $t=0,1, \ldots$ is

$$
\begin{aligned}
\mathrm{d} L= & \left\{\lambda d^{\prime}\left[c^{\prime} \cdot \frac{\partial p^{\prime}}{\partial m^{\prime}}+m^{\prime} \frac{\partial \phi^{\prime}}{\partial m^{\prime}}+\phi^{\prime}\right]\right. \\
& \left.+\mu^{\prime}\left[-v^{\prime} \cdot\left(1-\frac{m^{\prime} c^{\prime}}{p^{\prime} \cdot c^{\prime}} \cdot \frac{\partial p^{\prime}}{\partial m^{\prime}}\right)-v c^{\prime} \cdot \frac{\partial p^{\prime}}{\partial m^{\prime}}\right]\right) \mathrm{d} m^{\prime},
\end{aligned}
$$

where $\partial p^{t} / \partial m^{t}=\left(\partial p_{1} / \partial m^{t}, \ldots, \partial p_{N} / \partial m^{t}\right)$. The first term in (10) shows the impact of a change in real balances on the government budget while the second term shows the impact on the economy's resource constraint.

At an optimum the level of real balances will be chosen so that the expression in (10) equals zero. In order to assess the role of the optimum quantity of money rule in the optimal tax package it is therefore necessary to see if this expression equals zero at $m^{t} / p^{t} \cdot c^{t}=(m / p \cdot c)^{*}$ for all $t$. Recalling that $\phi=v=v^{\prime}=0$ when $m^{\prime} / p^{t} \cdot c^{\prime}=(m / p \cdot c)^{*}$, it follows that evaluated at $m^{\prime} / p^{t} \cdot c^{\prime}=(m / p \cdot c)^{*}$,

$$
\mathrm{d} L=\lambda d^{\prime}\left(c^{\prime} \cdot \frac{\partial p^{\prime}}{\partial m^{\prime}}+m^{\prime} \frac{\partial \phi^{\prime}}{\partial m^{\prime}}\right) \mathrm{d} m^{\prime}, \quad t=0,1, \ldots
$$

Evaluating (7) and (8) at $(m / p \cdot c)^{*}$ and using the resulting expressions in (11) it can be shown that $\mathrm{d} L / \mathrm{d} m^{\prime}=0, \forall t$, when $m^{t} / p^{t} \cdot c^{\prime}=\left(m / p \cdot c^{*}\right)$. Therefore the optimum quantity of money rule is a component of the optimal tax package.

To gain further insight into the intuition underlying the result that when money is an intermediate good the optimum quantity of money rule is part of the optimal tax structure, consider the steady-state, one good case shown in fig. 1. The production possibilities frontier is the outermost line in the diagram, $c^{t}=1-x^{t}$. If all tax revenues were raised by the inflation tax and returned to the consumer as lump-sum transfers, the equilibrium consumption/leisure combinations available to the consumer, given his optimal choice of real balances relative to expenditure, $m^{t} / p^{t} c^{t}=k(\cdot)$, would be given by the schedule $[1+\dot{v}(\cdot)] c^{\prime}=1-x^{\prime}$. The horizontal distance between the production possibilities frontier and this locus reflects the rising transactions costs the consumer bears as he increases his consumption. However, tax revenues are not returned to the consumer but used by the government to purchase goods. Therefore, in equilibrium the constraint facing the consumer is not $[1+v(\cdot)] c^{t}$ $=1-x^{t}$ but rather $q^{t} c^{t}=1-x^{t}$. The consumer's equilibrium is thus at $E$ where his indifference curve $\tilde{U}$ is tangent to his budget line. Given his consumption level, $\tilde{c}^{t}$, the labor required to produce the consumer's goods, $\tilde{l}^{t}$, can be found directly from the production possibilities frontier. In addition, it is also apparent that since the government is using inflationary finance the 


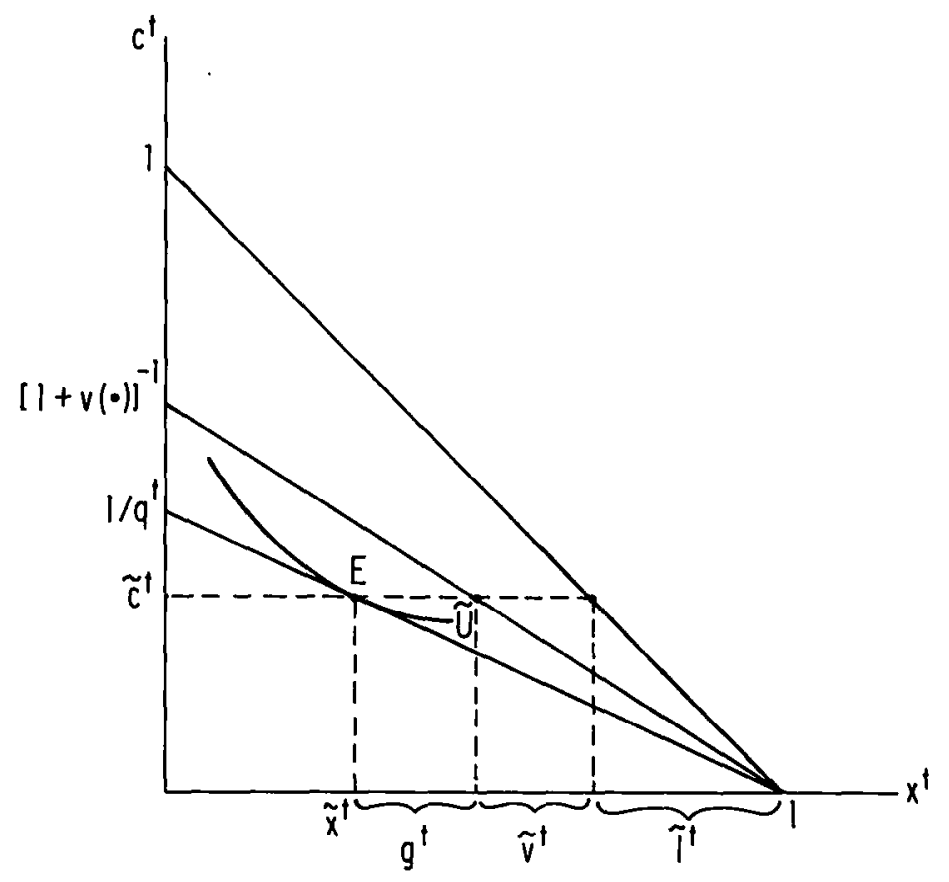

Fig. 1

consumer spends $\tilde{v}^{t}$ of his time transacting and government tax revenues are $g^{t}$. However, if the government eliminated the inflation tax and taxed consumption directly, then, holding the effective tax rate constant, government revenues would rise from $g^{t}$ to $g^{t}+\tilde{v}^{t}$ as the waste from excessive transactions costs was eliminated. The government could then dispose of this budget surplus by cutting tax rates. This would expand the consumer's opportunity set and increase his level of utility. Since the government can satisfy its budget constraint at a higher level of welfare by avoiding inflationary finance and relying solely on consumption taxes for revenue, the optimum quantity of money rule is a key element of the optimal tax structure.

\section{Conclusion}

The paper's key result, that in order to maximize private welfare the optimum quantity of money rule should be followed even when distorting taxes must be levied to raise revenue, is in sharp contrast to the earlier public finance based literature on the inflation tax by Phelps (1973) and others. The crucial feature of the model employed here that accounts for this difference in results is the explicit recognition of money's role as an intermediate good that helps to effect the conversion of scarce resources into final consumption goods. 
The paper thus provides an example which lends strong welfare theoretic support to the case for enacting Friedman's (1969) optimum quantity of money rule as well as highlighting the need to pay careful attention to the economic role served by money and how it is modeled when evaluating questions concerning the optimum rate of inflation.

\section{References}

Diamond, Peter A. and James A. Mirrlees, 1971, Optimal taxation and public production, I: Production efficiency, and II: Tax rules, American Economic Review 61, 8-27 and 261-278. Drazen, Allan, 1979, The optimal rate of inflation revisited, Journal of Monetary Economics 5, 231-248.

Faig, Miquel, 1986, Optimal taxation of money balances, Unpublished manuscript (Stanford University, Stanford, CA).

Friedman, Milton, 1969, The optimum quantity of money, In: The optimum quantity of money and other essays (Aldine, Chicago, IL) 1-50.

Helpman, Elhanan and Efraim Sadka, 1979, Optimal financing of the government's budget: Taxes, bonds, or money?, American Economic Review 69, 152-160.

Kimbrough, Kent P., 1986, Optimal taxation in a monetary economy with financial intermediaries, Unpublished manuscript (Duke University, Durham, NC).

Marty, Alvin L., 1978, Inflation, taxes, and the public debt, Journal of Money, Credit, and Banking 10, 437-452.

Pheips, Edmund S., 1973, Inflation in the theory of public finance, Swedish Journal of Economics $75,67-82$.

Sandmo, Agnar, 1976, Optimal taxation: An introduction to the literature, Journal of Public Economics 6, 37-54.

Siegel, Jeremy J., 1978, Notes on optimal taxation and the optimal rate of inflation, Journal of Monetary Economics 4. 297-305. 